\title{
"Big data, 4IR and electronic banking and banking systems applications in South Africa and Nigeria"
}

\begin{tabular}{|c|c|}
\hline \multirow{3}{*}{ AUTHORS } & Patrick Ajibade iD https://orcid.org/0000-0002-8608-8378 \\
\hline & R http://www.researcherid.com/rid/R-2448-2016 \\
\hline & Stephen M. Mutula \\
\hline ARTICLE INFO & $\begin{array}{l}\text { Patrick Ajibade and Stephen M. Mutula (2020). Big data, } 4 \text { IR and electronic } \\
\text { banking and banking systems applications in South Africa and Nigeria. Banks } \\
\text { and Bank Systems, 15(2), 187-199. doi:10.21511/bbs.15(2).2020.17 }\end{array}$ \\
\hline DOI & http://dx.doi.org/10.21511/bbs.15(2).2020.17 \\
\hline RELEASED ON & Wednesday, 24 June 2020 \\
\hline RECEIVED ON & Thursday, 20 February 2020 \\
\hline \multirow[t]{2}{*}{ ACCEPTED ON } & Sunday, 29 March 2020 \\
\hline & $(c)) \mathrm{EY}$ \\
\hline LICENSE & $\begin{array}{l}\text { This work is licensed under a Creative Commons Attribution } 4.0 \text { International } \\
\text { License }\end{array}$ \\
\hline JOURNAL & "Banks and Bank Systems" \\
\hline ISSN PRINT & $1816-7403$ \\
\hline ISSN ONLINE & $1991-7074$ \\
\hline PUBLISHER & LLC "Consulting Publishing Company "Business Perspectives" \\
\hline FOUNDER & LLC "Consulting Publishing Company "Business Perspectives" \\
\hline
\end{tabular}

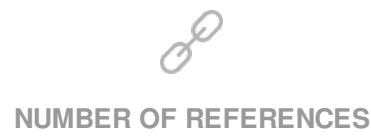

36

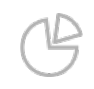

NUMBER OF FIGURES

5

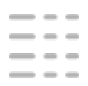

NUMBER OF TABLES

4

(C) The author(s) 2022. This publication is an open access article. 


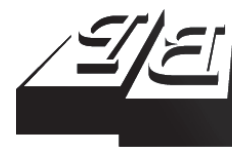

\section{BUSINESS PERSPECTIVES}

LLC "CPC "Business Perspectives" Hryhorii Skovoroda lane, 10, Sumy, 40022, Ukraine www.businessperspectives.org
Received on: $20^{\text {th }}$ of February, 2020 Accepted on: $29^{\text {th }}$ of March, 2020 Published on: $24^{\text {th }}$ of June, 2020

(c) Patrick Ajibade,

Stephen M. Mutula, 2020

Patrick Ajibade, Research Scholar, Faculty of Humanities, Information Studies Department, University of KwaZulu-Natal, South Africa. (Corresponding author)

Stephen M. Mutula, Ph.D., Professor of Information Studies, Faculty of Humanities, School of Social Sciences, Information Studies Programme, University of KwaZulu Natal, South Africa.

\section{BIG DATA, 4IR AND ELECTRONIC BANKING AND BANKING SYSTEMS APPLICATIONS IN SOUTH AFRICA AND NIGERIA}

\begin{abstract}
Efficient banking solutions are an integral part of the business integration of South African and Nigerian economies as the two largest economies in the continent. Security, effectiveness, and integration of banking systems are critical to the sustainable development of the African continent. Therefore, an empirical analysis of the production of research on banking services and systems was conducted. The aim of the study was to examine the robustness of the research findings on banking systems in terms of their importance for the economic sustainability of the continent in the era of the fourth in dustrial revolution. The study adopted a bibliometric analysis using software clusters to visualize the results. Due to higher visibility of outputs and likely citations, the results showed that the key terms from Google Scholar are ranked higher than outputs from Scopus. Main research interests were related to internet banking $(f=70)$, e-payment systems ( $f=57)$, telephone banking $(f=56)$, automated teller machines $(f=54)$, and mobile banking $(f=40)$. The results also showed a very low research interest in the technical aspect of online banking services such as security $(f=19$, TLS $=40)$, authentication ( $\mathrm{f}=17$, TLS $=33$ ), network security $(\mathrm{f}=13$, TLS $=33$ ), computer crime $(\mathrm{f}=16$, TLS $=42)$, and online banking $(\mathrm{f}=11, \mathrm{TLS}=32)$. The study found there were insufficient outputs in the area of the fourth industrial revolution (4IR) and banking services in Africa. Future research trends should examine the impact of the 4IR and big data on the banking system, regional economic integration, and sustainable growth in the continent.
\end{abstract}

\section{Keywords big data, banking system, information technology, mobile banking, 4IR}

\section{JEL Classification C88, G21}

\section{INTRODUCTION}

A real-time flow of information that facilitates the rapid exchange of knowledge through the adoption of big data will drive the growth, competitiveness, and productivity of companies (Pezzuto, 2019), including banking operations. Banking systems play a key role in facilitating sustainable growth and regional integration. In this era of integrated Information Technology (IT), the networked environment is characterized by cloud computing, the Internet of Things, and big data technology. Hence, virtual business information systems must be adapted by banks to take advantage of these technologies. A recent study hypothesized that mobile banking services, cryptocurrency, and e-commerce platforms that is built on sustainable, but enhanced networked solutions, will drive future global enterprises, including banking solutions (Pezzuto, 2019). And future banking systems will continue to provide e-payment services, mobile or virtual banking, and electronic fund transfers, provided that matured business and IT alignment is maintained. Considering the above, do the two leading African countries have an improved IT infrastructure and broadband to sustain their economic growth and agile banking services? In the 
integrated business environment, with advances in the IT infrastructure, banking services must be configured to respond and adapt to an integrated and networked technology to provide virtual banking services. This study, therefore, provides a bibliometric analysis of knowledge production in this research domain.

The importance of a robust banking service that can ensure the sustainability of a national economy cannot be overestimated. A study by the World Bank indicated that $66 \%$ of the African population does not use formal banking systems. The African continent leads the world in terms of the use and deployment of mobile money transfers (Ohene-Afoakwa \& Nyanhongo, 2017). The African continent remains largely dependent on the banking and financial services from the United States of America. Unless Africa develops and consolidates its business information systems with a unique banking system architecture, there will be no significant and sustainable development in the continent. For example, some observe that the sustainable growth of any economy depends on how efficient the banking system is in driving economic trajectories (Jeucken, 2010). Besides, the usual importance of an efficient banking system is to promote economic growth, ensure green investment financing, and facilitate agile regional economic integration. A robust banking services architecture across the continent will eliminate the over-dependence on foreign exchanges for all regional transactions. However, some of the current challenges in the continent hinge on the inability of academics to assist the government (through research) in prototyping continental banking system architecture that responds to the embryonic African market.

Knowledge production for agile banking services, especially in the era of big data and cloud computing, is limited. There is a lack of research on the agile banking system architecture, and insufficient literature on the plethora of challenges around banking systems in the continent, especially in Nigeria and South Africa. Some of the available literature only focuses on the consumers' attitudes towards internet and cellphone banking services in South Africa (Maduku, 2011, 2013). There is a low uptake in market penetration of banking services in South Africa (Gill, 2010), and the question remains, how do users measure e-banking service quality, and is there a mechanism to validate electronic banking (ebanking) transactions? Recently, in South Africa, there have been cases of a lack of synergy between epayments and account settlements. In which a third party deducts from a client bank account when the third-party contract had been terminated. This meant that although the contractual obligations were no longer in effect, the merchants kept deducting money from the clients, and the clients/bank could not stop such transactions. The weak interfaces of internet applications and mobile apps show that the service functions and business requirements of the mobile and internet banking infrastructure are not robust enough to respond to user needs. However, studies in this domain have failed to highlight these challenges.

\section{LITERATURE REVIEW}

\subsection{Problem statement}

This paper examined the governance of banking information systems. It evaluated the production of knowledge on banking services and banking systems in Africa, based on the results of scientific publications. One challenge of mobile banking is the lack of a strong network infrastructure (Chaudhry, 2015), and this can pose a serious threat to economic activities, especially within the rural/farming towns in Nigeria that have no easy access to physical banking premises. Despite con- siderable efforts and outputs on banking services and electronic accounting information systems, several gaps have not been covered exhaustively in the literature. The unavailability and misuse of automated teller machines (ATMs) are some of the problems facing Nigerian banking systems. Some studies have examined the negative impact of an ATM, as it exacerbates fraud in Nigeria and leads to other barriers of mobile banking (Agwu, Okpara, Ailemen, \& Iyoha, 2014; Ogbuji, Onuoha, \& Izogo, 2012). It has been established that innovation in networked technologies is central to banking services deliveries (Ilo, Wilson, \& Nnanyelugo, 2014). Despite the reported fraud cases and appre- 
hensions about online banking risks, banking services are still being introduced to users. Another barrier to introducing internet banking services in Nigeria hinges on the constant technological changes (Agwu, 2015) that have led to an increase in the level of threats and the risk of cyber frauds.

It is expected in this era of technological advancement and its ability to contribute to developing e-commerce that most research in banking applications should focus on the nexus between banking systems and cloud computing, cloud infrastructure, Internet of Things, and cryptocurrency amongst others. In recent years, some of the research focus has been on the demographic effects on the mobile banking adoption by clients (Abayomi et al., 2019), digital signature, e-banking authentication, (Okereke \& Ezugwu, 2014), and this study on e-signature and authentications did not even examine cryptography and cloud infrastructure and other relevant technologies. Other research focuses were on the quality of e-banking in Nigeria (Olowokere \& Olufunmilayo, 2018) and strategies for improving the e-banking security framework (Sarjiyus, Oye, \& Baha, 2019). None analyzed the advanced technologies, such as big data and cloud computing. But this study showed a lack that existed in knowledge production in banking information systems vis-à-vis the impact of big data and 4IR on banking services, especially in Nigeria and South Africa. As most research interest in banking services was on corporate governance (Ngerebo-A \& Yellowe, 2012), customers' use of internet banking (Agwu, 2017; Ozuru \& Opara, 2014), the impact of ATM on the automated banking services (Ali, 2016), and e-banking authentication (Okereke \& Ezugwu, 2014). Unfortunately, challenges facing the continent in terms of financial services architecture are beyond these research focus. For example, to travel from South Africa to Nigeria, travelers still rely on buying the US dollar, since Nigerian currency is not available at the airport in Johannesburg. At the same time, South African rand could be purchased at the airport in Lagos. But how can African development be strengthened, while the economies depend heavily on the Euro and the US dollar? Besides, when paying for purchases in the US dollar using VISA or MASTER bank cards, an additional fee of USD 23.55 is charged. Such extra costs from a million South Africans and Nigerian could (potentially) transfer almost USD 24 million out of the continent. Yet, African scholars' knowledge production has failed to address some of these critical challenges in the banking system architecture. Therefore, this study uses bibliometrics as a tool for mapping knowledge production (Ajibade \& Mutula, 2018), which is important in evaluating the research focus of banking services in Nigeria and South Africa.

\subsection{Banking services in Nigeria}

An attempt in Nigeria, 50 years ago, to examine the importance of online payments and electronic banking services (Agboola, 1970), as well as technologies and internet services, has increased the flexibility of banking services (Sarjiyus, Oye, \& Baha, 2019). Sarjiyus, Oye, and Baha (2019) focused on evaluating the online security risk of electronic banking systems. However, they did not examine the role of the fourth industrial revolution (cloud infrastructure and big data) in providing e-banking and likely associated security implications. In Nigeria, it was established that poor electricity and ICT infrastructure were major impediments facing banking services (Essia \& Anwana, 2012). However, up to date scientific inquiries must reflect all the major problems facing the banking systems, including the implications of using cryptocurrencies and fraud prevention. Besides, the fourth industrial revolution (4IR), big data, and the 5G (generation) mobile network infrastructure are likely to revolutionize future banking services. Thus, this bibliometric analysis is important for mapping the direction of research in this domain to establish the relevance of knowledge production in the continent.

There are many problems in the continent associated with the adoption and use of banking services. Using Nigeria as a case study regarding what has not been reported in recent studies. For example, in Ekiti State, Nigeria, there are major banks with no physical banking halls/buildings in major towns and sub-rural communities in the Ekiti-West, Oye, and Ikole Local Governments of the state. These problems are beyond the fairytale and cosmetic analysis of challenges that have been reported in the literature, such as customer satisfaction with e-banking (Musa, Habib, \& Muhammad). For instance, a study reported ease 
of capital movement using the e-banking system across the border (Nnamani \& Makwe, 2019). Howbeit, the ease of cash movement depends on one's geographical location within the country. But it would have been acceptable to have robust banking applications and mobile banking systems that can bridge this digital divide in mobile banking systems. Unfortunately, major infrastructural challenges are inhibiting the adoption of mobile applications in most of these areas. Due to lack of access to mobile data or internet facilities, a lack of electricity supply to recharge flat phone batteries, etc. A recent study indicated that only $20 \%$ of Nigerian households had access to networked information technology. Another challenge of e-banking systems is the ability to confirm the identities of transacting parties to curb fraud and increase user satisfaction (John \& Roitimi, 2014).

\subsection{Banking services in South Africa}

South Africa and Nigeria are the two largest economies in Africa; therefore, monetary services must be robust to drive the two economies. However, the financial architecture/infrastructure between the two nations is not aligned or integrated. Furthermore, there is a lack of literature to support executable strategies aimed at harmonizing business and IT banking services to stimulate regional economic integration between Nigeria and South Africa (Ajibade \& Mutula, 2020a). Many studies (Maduku, 2013) have explored banking services in South Africa and the predictability of bank clients' attitudes. In 2018, Nyoka's study focused on mobile banking in South Africa and mediating factors for its adoption (Nyoka, 2018). While the focus on mobile banking services, criteria for transactional banking services preference, and factors determining the consumer use of mobile banking is noteworthy (Kabanda, Downes, \& dos Ramos, 2012), some of the research focus of banking services in South Africa should be on integrating the fourth industrial revolution (4IR) technology into banking services. There seems to be a huge gap in the literature, especially in terms of the interconnectedness of the 4IR and banking services in Africa. For instance, the challenge of some of these open-source technologies, especially cryptocurrencies, as a disruptive technology to banking services in Africa should be addressed. There are malicious parties using cryptocurrencies to ask for ransom. For example, a website belonging to the Johannesburg Municipality was hacked, and the hacker demanded ransom in Bitcoins for the site to be functional again. Some of the knowledge production trends on digitization and mobile banking in the networked environment have not covered these challenges in South Africa and Nigeria.

\section{METHODOLOGY}

The study used a bibliometric analysis as a useful quantitative tool to map the trend of knowledge production (Ajibade \& Mutula, 2018). Data were extracted from the Web of Science (WoS) (n $=58)$, Google Scholar (GS) $(n=662)$ and Scopus databases. However, there were 776 total global outputs from the Web of Science. Only 58 outputs were from scholars from Africa, with these metrics: h-index $=9, \mathrm{AVC}=4.91$ (average citations per item), and a total sum cited times STC $=285$ from 269 citing articles. Because most outputs in the WoS were replicated in Scopus, it was decided to use the data from Scopus and GS for the analysis. However, as the outputs in the Scopus database was insignificant, it was decided to include all outputs from all countries in the database using the following search strings (wildcard such as "* or ?" were not used, since the search strings include the name of countries, a term known with no ambiguity):

TITLE-ABS-KEY ("banking services") AND (Limit-To (Affilcountry, "South Africa") Or Limit-To (Affilcountry, "Nigeria") Or Limit-To (Affilcountry, "Ghana") Or Limit-To (Affilcountry, "Egypt") Or Limit-To (Affilcountry, "Ethiopia") Or Limit-To (Affilcountry, "Tunisia”) Or Limit-To (Affilcountry, "Morocco") Or Limit-To (Affilcountry, "Zimbabwe") Or Limit-To (Affilcountry, "Kenya") Or Limit-To (Affilcountry, "Mauritius") Or LimitTo (Affilcountry, "Cameroon") Or Limit-To (Affilcountry, "Zambia”) Or Limit-To (Affilcountry, "Libyan Arab Jamahiriya") Or Limit-To (Affilcountry, "Sudan") Or Limit-To (Affilcountry, "Tanzania") Or Limit-To (Affilcountry, "Uganda”) Or Limit-To (Affilcountry, "Algeria") Or Limit-To (Affilcountry, "Botswana") Or Limit-To (Affilcountry, "Malawi") Or Limit-To (Affilcountry, "Rwanda") Or Limit-To (Affilcountry, "Somalia")). 
Based on these search strings, results were filtered out that were not published in English. Data visualization was used to present key phrases and research focus in this research domain. Research visualization is an important tool for presenting findings in graphical details based on this model specification in 2.1 (Waltman, Van Eck \& Noyons 2010; Van Eck \& Waltman, 2014; Ajibade \& Mutula, 2020b).

\subsection{Visualization of a model specification bibliometric network}

$$
s_{i j}=\frac{2 m a_{i j}}{k_{i} k_{j}}, \text { where } a_{i j}=a_{j i},
$$

showing the normalization strength construct weights of network nodes $i$ and $j$;

$k_{i}\left(k_{j}\right)$, thus, $k_{i}=\sum_{j} a_{i j}, \mathrm{~m}=\frac{1}{2} \sum_{i} k_{i}$,

and $s_{i j}$ denotes similarity of $i$ nodes.

\subsection{Clustering model}

$$
V\left(x_{1}, \ldots, x_{n}\right)=-\frac{\gamma^{2}}{2 m} \sum_{i<j} \delta\left(x_{i}, x_{j}\right) w_{i j}\left(c_{i j}-\gamma \frac{c_{i} c_{j}}{2 m}\right),
$$

as $\delta\left(x_{i}, x_{j}\right)$ equals 1 if $x_{i}=x_{j}$ and 0 .

$$
\begin{aligned}
& V\left(x_{1}, \ldots, x_{n}\right)=-\frac{\gamma^{2}}{2 m} V\left(x_{1}, \ldots, x_{n}\right)+ \\
& +\frac{1}{2 m} \sum_{i<j}\left(c_{i j} \frac{2 m c_{i j}}{c_{i} c_{j}}-\gamma\right) .
\end{aligned}
$$

However, model 2 was based on model 1 by multiplying a constant and adding a constant as defined in model 1.

\subsection{Co-authorship metric}

The co-authorship metrics were determined based on the analysis of Perianes-Rodriguez, Waltman, and Van Eck (2016) in constructing a bibliometric network (Waltman, Van Eck, \& Noyons, 2010). The model in (a) represented co-authorship, and (b) represented the fractional counting methods of co-authorship, which was used in this paper.

$$
{ }_{(a)} n_{k}=\sum_{i=1}^{N} a_{i k} \quad{ }_{(b)} u i_{i j}^{*}=\sum_{K=1}^{M} \frac{a_{i k} a_{j k}}{n_{k}-1},
$$

where $N$ is the number of researchers in the network analysis; $M$ is the number of publications used in the network analysis; $a_{i k}=1$ if a researcher $i$ is the author of a publication $k$ and 0 otherwise, while the $n_{k}$ represents the number of authors for any particular publication $k$.

The authors processed outputs from Google Scholars (GS) and extracted the abstracts to compare the key terms with those in Scopus. Out of 1,986 terms/keywords in the GS output, it was decided to find out terms that occurred at least fifteen (15) times. Only 39 terms met this minimum threshold. After that, $60 \%$ of the most relevant of the 39 terms were selected, which is 23 terms. Besides, other terms such as institution, author names, and research terms that were not relevant to banking services and systems were filtered out (see Table 4).

\section{RESULTS}

\subsection{Availability of banking services in Nigeria}

A living-lab method was used, which is an innovative research methodology often applied to open technological research projects (Almirall \& Wareham, 2008). It is useful in determining the failure or success of deployed technological products (Coorevits, Seys, \& Schuurman, 2014), such as banking systems and services, to test the availability of banking services. Undoubtedly, all banks have their branches in Lagos, but the distance from Lagos to Ekiti State on E1/A122 expressway is $394 \mathrm{~km}$. Ekiti State population is 2.3 million, and agriculture provides over $75 \%$ of employment and income for the population. Yet, mobile access, network services connectivity are limited in most farm locations. However, the study tested mobile banking services and the proximity of banking halls in "Oke Ayedun" of Ikole Local Government of Ekiti State (see Figure 1). Unfortunately, it appeared there was only one Wema banking hall in the town where the researcher had searched for the banking hall using the GPS-enabled device on the mobile phone. However, agile banking ap- 


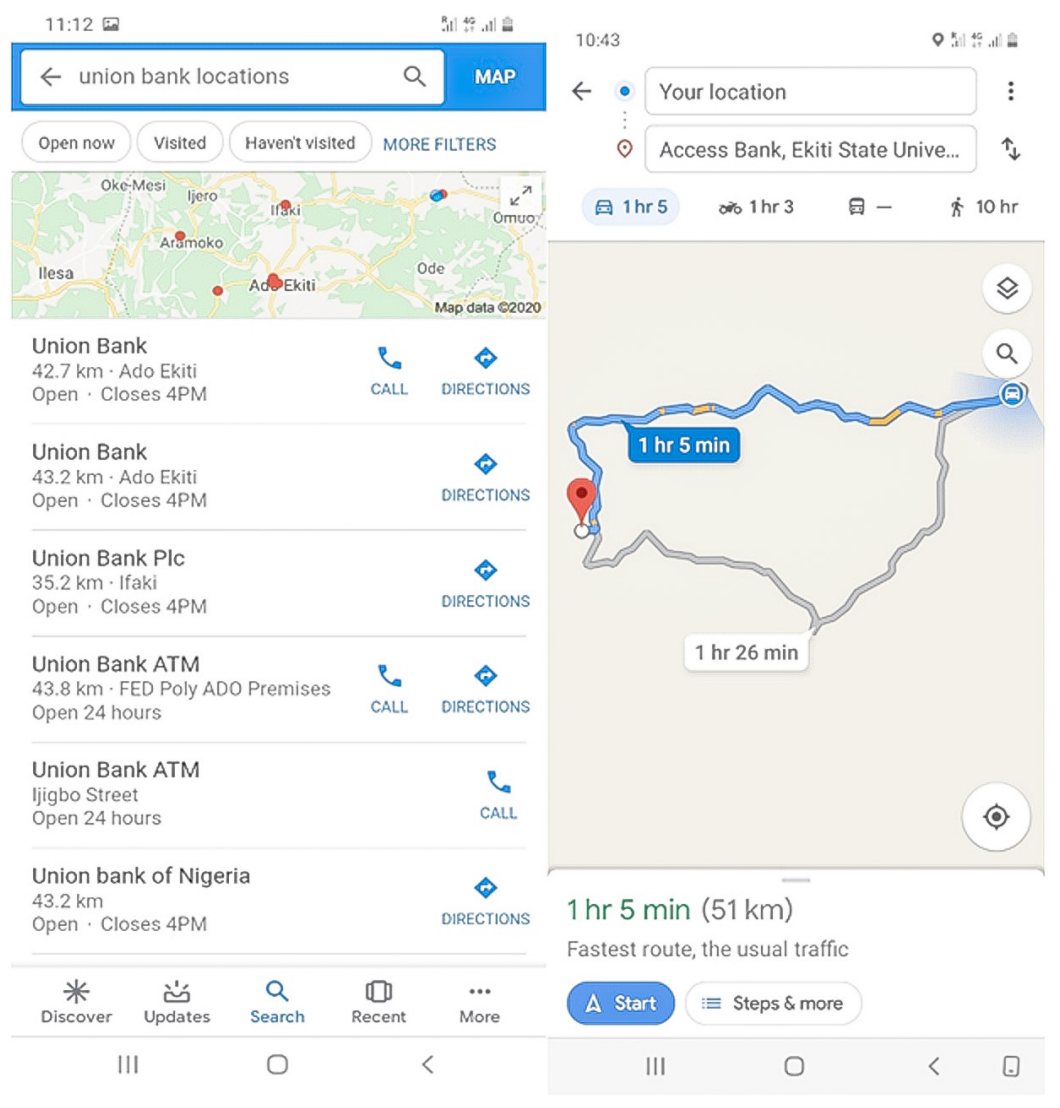

Figure 1. Banking halls and services availability in some Local Government of Ekiti State

plications would have been ideal instead of traveling between $23 \mathrm{~km}$ to $51 \mathrm{~km}$ to the state capital to access banking locations and round trips of 102 $\mathrm{km}$ to set up a mobile banking application should there be a need. Therefore, it would be very convenient to have mobile banking systems to cater for the people in these areas. Figure 1 shows the current nearest access and union banks, respectively, and the distance to the researcher's current location, a reality that none of the previous studies have examined. Therefore, there is a need to assess knowledge production in this research area and to show some of the existing gaps in the body of knowledge.

Co-citation analysis is important to show the relatedness of outputs based on the number of times they are cited together. For the analysis, co-citation was chosen, whereas for the unit of analysis, cited sources were selected and the full counting methods were applied.

Out of the total number $(n=9,285)$ of global sources, journal sources were selected with at least
10 citations per source to calculate the number of co-citations. Only 54 sources met this minimum threshold (see Figure 2 and Table 1). The finding showed the top 5 ranked citations by sources, which accounted for almost a quarter (28.1\%) of the total outputs $(f=2,250)$. Journal sources with higher total link strength (TLS) provided the strength of the impact of collaboration links among journal sources, and this was reported in other bibliometric visualization in a different field of studies (Nadzar, Bakri, \& Ibrahim, 2018; Wang, Xing, Zhu, Dong, \& Zhao, 2019). The network analysis (see Figure 2) indicated the TLS of outputs, the similarity, the percentages of the total link strength from the top five journal sources that accounted for $32.3 \%$ in relation to the other sources. This indicated that these journals were closely cited by sources working on banking services and systems in comparison with the other 54 journal sources in this analysis. This means that the visibility of authors and their outputs will be higher, probably with greater impact than if the results were published in the lower $67 \%$, which accounted for the remaining journal sources. 


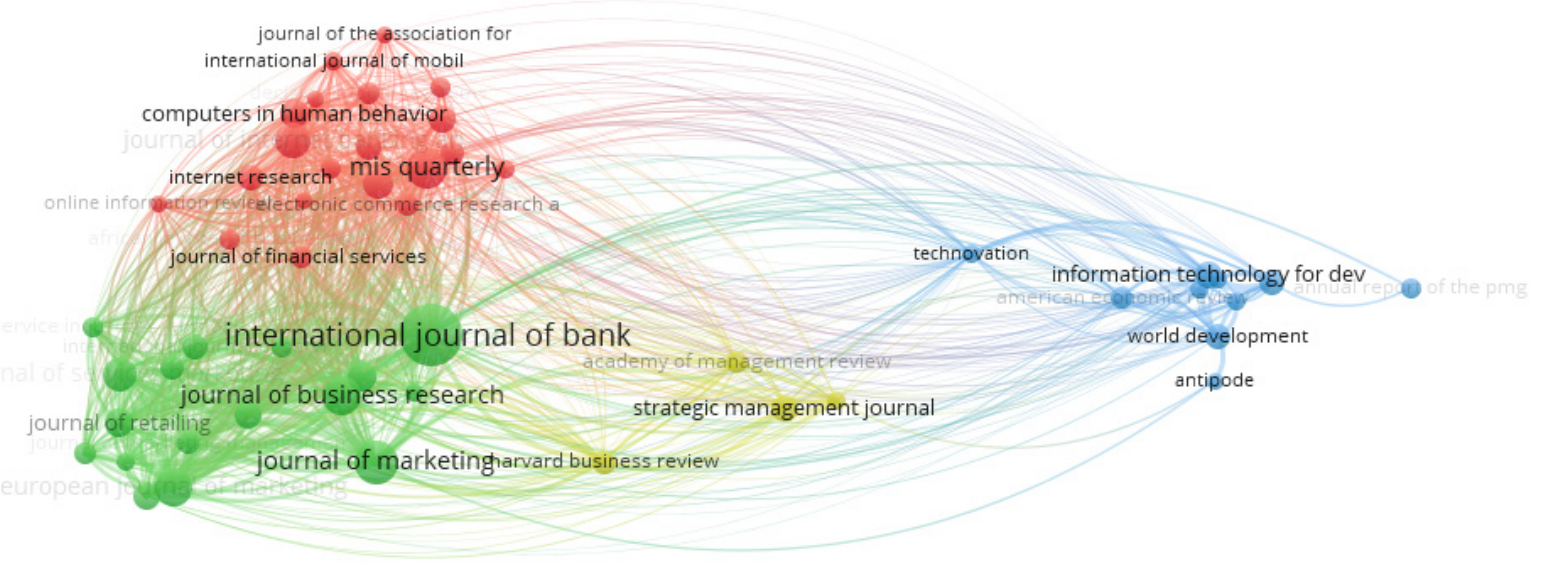

Figure 2. Output distribution by sources

Table 1. Co-citation outputs by source and citation analysis

\begin{tabular}{|c|c|c|c|c|}
\hline Top 10 outputs by journal sources & $\mathrm{TC}(f=2,550)$ & $\%$ & $\operatorname{TLS}(n=50,214)$ & $\%$ \\
\hline International Journal of Bank Marketing & 270 & 10.6 & 5,372 & 10.7 \\
\hline Journal of Marketing & 129 & 5.1 & 3,318 & 6.6 \\
\hline MIS quarterly & 115 & 4.5 & 1,916 & 3.8 \\
\hline Journal of Business Research & 102 & 4.0 & 2,742 & 5.5 \\
\hline European Journal of Marketing & 100 & 3.9 & 2,861 & 5.7 \\
\hline Journal of Internet Banking and Commerce & 84 & 3.3 & 743 & 1.5 \\
\hline Journal of Services Marketing & 81 & 3.2 & 2,178 & 4.3 \\
\hline International Journal of Information Management & 65 & 2.5 & 1,210 & 2.4 \\
\hline Computers in Human Behavior & 61 & 2.4 & 1,482 & 3.0 \\
\hline Journal of Marketing Research & 60 & 2.4 & 1593 & 3.2 \\
\hline
\end{tabular}

Note: TC - total citation, TLS - total link strength.

\subsection{Co-authorship by countries}

The collaboration scheme shows countries that are conducting joint research on banking systems in Nigeria and South Africa. It revealed a growing trend between scholars in the continent and the rest of the world (see Figure 3). However, South African scholars enjoyed more international collaboration compared to Nigerian scholars, as indicated in the co-authorship network (see Table 2):
South African scholars accounted for over 50.7\% from $(n=278)$ outputs, while Nigerian scholars' ( $\mathrm{n}=150$ ) outputs only accounted for $27.4 \%$. The citation analysis indicated that South African citations (RSA) accounted for $50.7 \%$ of the total outputs in comparison with Nigerian (NIG) $27 \%$. Similarly, the RSA citation is 1,226 , accounting for $36 \%$, and NIG citation is 974 , accounting for $24.6 \%$ (see Table 2), showing the top 10 countries with which scholars from Nigeria and South Africa col-

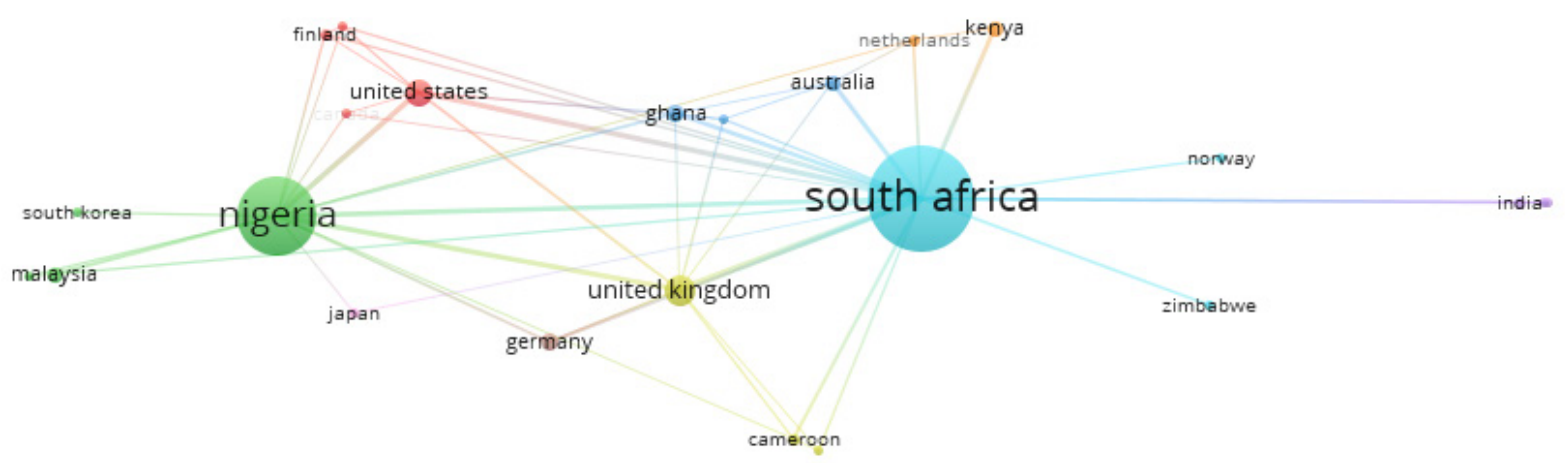

Figure 3. International collaboration based on co-authorship by countries 
Table 2. Co-authorship outputs and citation analysis by countries

\begin{tabular}{|c|c|c|c|c|c|}
\hline Country & Documents & $\%$ & Citations & $\%$ & TLS \\
\hline South Africa & 278 & 50.7 & 1,426 & 36.0 & 90 \\
\hline Nigeria & 150 & 27.4 & 974 & 24.6 & 48 \\
\hline United Kingdom & 23 & 4.2 & 576 & 14.5 & 36 \\
\hline United States & 20 & 3.6 & 191 & 4.8 & 29 \\
\hline France & 3 & 0.5 & 178 & 4.5 & 6 \\
\hline Netherlands & 4 & 0.7 & 149 & 3.8 & 6 \\
\hline Australia & 7 & 1.3 & 75 & 1.9 & 11 \\
\hline Canada & 2 & 0.4 & 57 & 1.4 & 3 \\
\hline Germany & 8 & 1.5 & 46 & 1.2 & 10 \\
\hline Ghana & 8 & 1.5 & 45 & 1.1 & 13 \\
\hline South Korea & 3 & 0.5 & 41 & 1.0 & 2 \\
\hline Cameroon & 4 & 0.7 & 38 & 1.0 & 8 \\
\hline Kenya & 7 & 1.3 & 38 & 1.0 & 8 \\
\hline
\end{tabular}

laborate on banking system research. By comparison, South African outputs were almost doubled that of Nigeria in terms of the total outputs and citations counts (Table 2).

\subsection{Mapping of key phrases and co-occurrence analysis of banking systems}

Co-occurrence analysis examined the most important terms and directions of research in banking services/systems since co-occurrence analysis revealed the direction of research and concentration of the researcher focus (Wang et al., 2019). However, by visualizing co-occurrence analysis, it is possible to identify research areas not extensively covered, thus, showing gaps that need to be explored for future studies. All keywords that occurred at least ten (10) times were analyzed and selected, and out of the total 2,493 keywords, only 35 keywords met at least 10 thresholds. The visualization network (Figure 4) and the breakdown (Table 3) indicated the predominant trend and area of focus of banking systems and mobile applica-

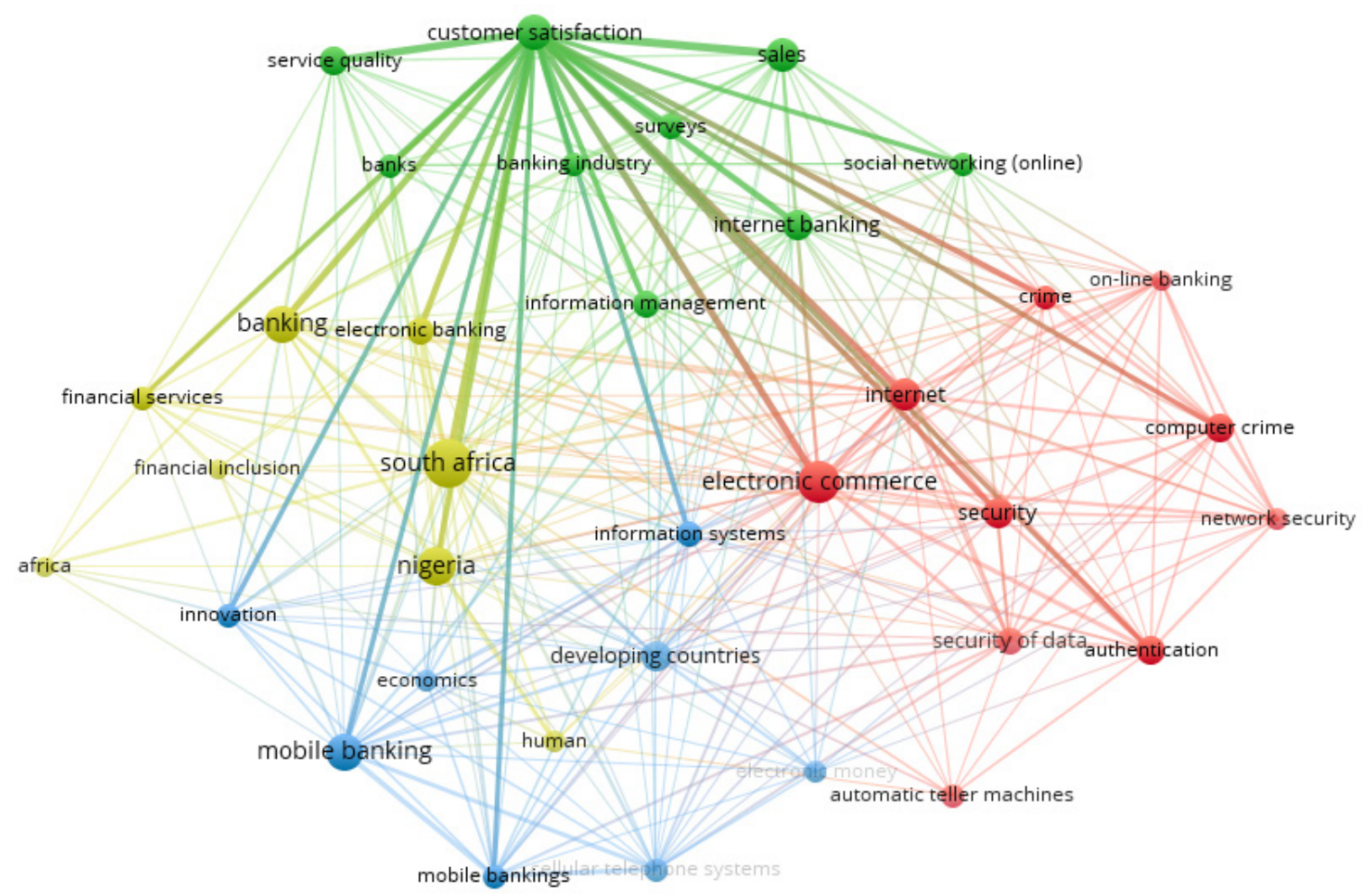

Figure 4. Top 35 keyword co-occurrences (Scopus dataset) 
Table 3. Top 20 co-occurrences of key phrases and all major terms arranged based on the TLS $(f=1,300)$ of the Scopus database

\begin{tabular}{|c|c|c|c|c|c|}
\hline Ranking & Keywords & $f(618)$ & $\%$ & $\operatorname{TLS}(f=1,300)$ & $\%$ \\
\hline 1 & Mobile banking & 40 & 6.5 & 98 & 7.6 \\
\hline 2 & Electronic commerce & 38 & 6.1 & 94 & 7.2 \\
\hline 3 & South Africa & 52 & 8.4 & 88 & 6.8 \\
\hline 4 & Internet & 20 & 3.2 & 63 & 4.8 \\
\hline 5 & Customer satisfaction & 27 & 4.4 & 60 & 4.6 \\
\hline 6 & Sales & 24 & 3.9 & 53 & 4.1 \\
\hline 7 & Banking & 28 & 4.5 & 47 & 3.6 \\
\hline 8 & Data security & 19 & 3.1 & 47 & 3.6 \\
\hline 9 & Developing countries & 23 & 3.7 & 45 & 3.5 \\
\hline 10 & Internet banking & 19 & 3.1 & 44 & 3.4 \\
\hline 11 & Cellular telephone systems & 15 & 2.4 & 42 & 3.2 \\
\hline 12 & Computer crime & 16 & 2.6 & 42 & 3.2 \\
\hline 13 & Security & 19 & 3.1 & 40 & 3.1 \\
\hline 14 & Nigeria & 32 & 5.2 & 38 & 2.9 \\
\hline 15 & Information management & 15 & 2.4 & 37 & 2.8 \\
\hline 16 & Information systems & 13 & 2.1 & 34 & 2.6 \\
\hline 17 & Authentication & 17 & 2.8 & 33 & 2.5 \\
\hline 18 & Network security & 13 & 2.1 & 33 & 2.5 \\
\hline 19 & On-line banking & 11 & 1.8 & 32 & 2.5 \\
\hline 20 & Crime & 10 & 1.6 & 31 & 2.4 \\
\hline 21 & Electronic banking & 15 & 2.4 & 27 & 2.1 \\
\hline 22 & Innovation & 10 & 1.6 & 27 & 2.1 \\
\hline 23 & Social networking (online) & 10 & 1.6 & 27 & 2.1 \\
\hline 24 & Banking industry & 10 & 1.6 & 25 & 1.9 \\
\hline 25 & Financial services & 11 & 1.8 & 20 & 1.5 \\
\hline
\end{tabular}

Table 4. Keyword relevance based on Google Scholar outputs

\begin{tabular}{|c|c|c|c|c|}
\hline Ranking & Term & $f(346)$ & $\%(f)$ & Relevance score \\
\hline 1 & Internet banking & 70 & 20.2 & 1.1 \\
\hline 2 & Electronic payment system & 57 & 16.5 & 1.4 \\
\hline 3 & Telebanking service & 56 & 16.2 & 1.3 \\
\hline 4 & Automated teller machine & 54 & 15.6 & 3.5 \\
\hline 5 & Marketing & 38 & 11.0 & 1.9 \\
\hline 6 & Business & 37 & 10.7 & 1.3 \\
\hline 7 & Management & 34 & 9.8 & 1.0 \\
\hline
\end{tabular}

tion knowledge production in Nigeria and South Africa. Anyway, South African output visibility (ranked $3^{\text {rd }}$ ) was higher than the Nigerian output that was ranked $14^{\text {th }}$ (see Table 4). The comparative data (see Tables 3 and 4 from Scopus and Google Scholar) indicated the focus of studies on banking systems, since electronic commerce $(f=38,6.1 \%)$ was the most used term in Scopus publications, in comparison with Google Scholar (GS) with internet banking $(f=70,20.2)$ as the most important term (see Tables 3 and 4 for details). The total link strength (TLS) is useful in measuring the strength or impact of a term, journal sources, or the impact of an author, institution, or citations (Ajibade \& Mutula, 2018; Wang et al., 2019).
In Figure 4, a different color in the network cluster indicated a keyword with similar relationships and focus area that are closely related. The figure shows all the ranked keywords ( $\mathrm{f}=$ 618 ) and the total link strength $(f=1,300)$ of all the keywords. The red cluster dealt with information security and authentication ( $\mathrm{f}=17$, TLS $=33)$; network security $(\mathrm{f}=13$, TLS $=33)$; computer crime $(f=16$, TLS $=42)$; network security $(\mathrm{f}=13$, TLS $=33)$; online banking $(\mathrm{f}=11$, TLS $=32$ ); automated teller machines ( $\mathrm{f}=14$, TLS $=12)$; information management $(\mathrm{f}=15$, TLS $=$ 37 ); security $(\mathrm{f}=19)$; and ( $\mathrm{TLS}=40)$; electronic money $(\mathrm{f}=13$, TLS $=18)$; and automated teller machines $(f=14$, TLS $=12$ ). 


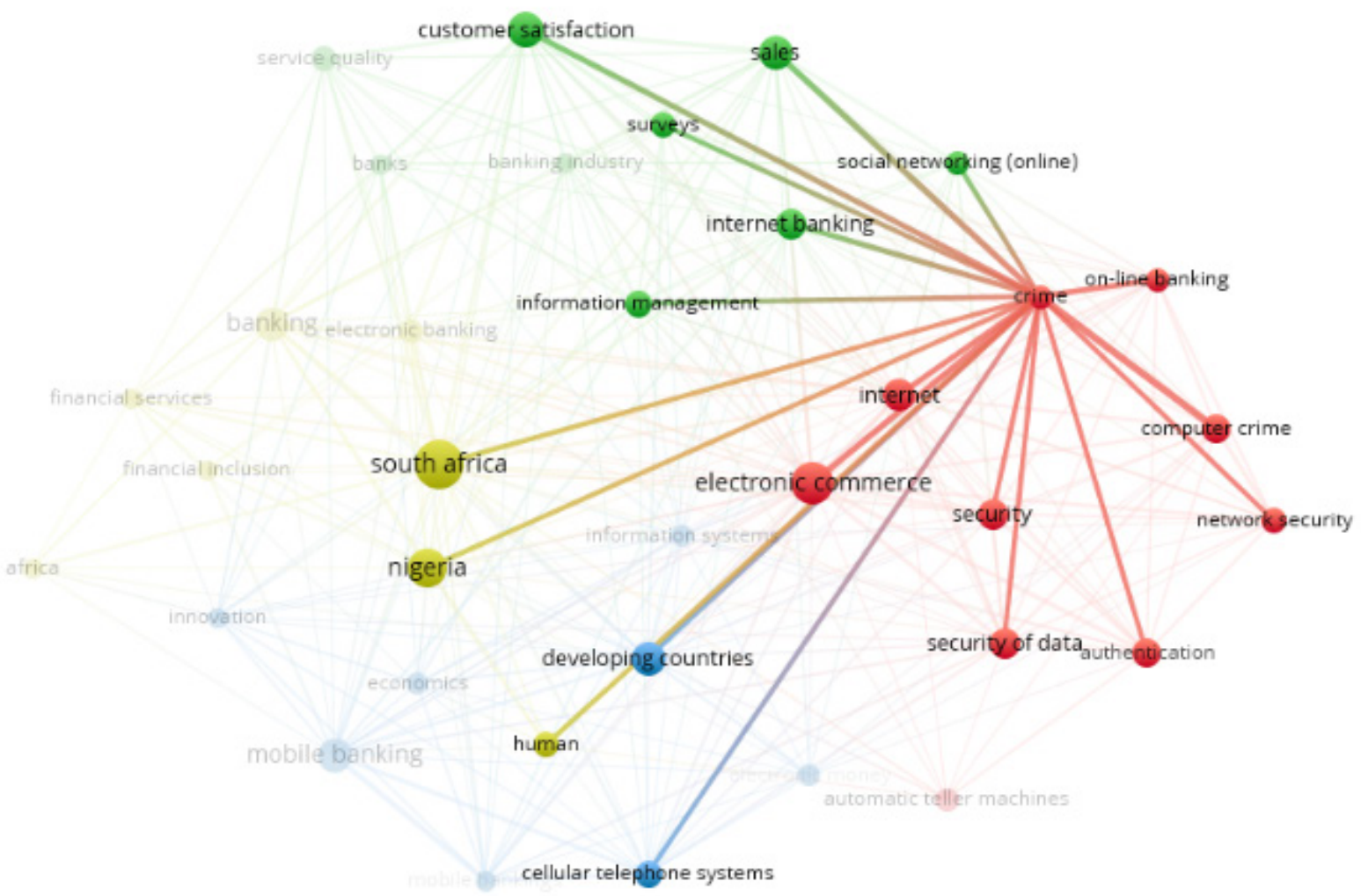

Figure 5. Isolated key phrases related to crime and banking systems

From Figure 4, all relevant keywords related to crimes were further isolated (see Figure 5), as this clustering network was useful for accessing areas that have been researched in banking systems about crimes, frauds, etc. and other areas not yet explored in banking research. It would also help mobile banking (Apps) designers to come up with areas to further explore in predicting service and business requirements for their system solutions. It showed the interrelatedness of key phrases, based on the number of documents in which they occurred together, to reveal the focus of research and the prevalence of knowledge production.

\section{CONCLUSION}

This bibliometric study quantitatively analyzes outputs on banking services and systems (BS) in Africa, with a focus on Nigeria and South Africa. The study presented main research areas, most relevant key terms, and their TLS, the direction of knowledge production in banking services in Nigeria and South Africa, and technologies related to the analysis of banking systems. The study concluded there was a lack of growth in terms of outputs and focus on banking applications in terms of cryptocurrency technologies, the impact of big data, cloud infrastructure and authentication of an online transaction, artificial intelligence, and e-commerce payment execution amongst others.

The study summarized outputs on banking services, top 10 high-impact journals, where these outputs were published, major countries collaborating with scholars from the continent to publish on banking systems, and trends in banking research, by summarizing past and present and using visualization networks to provide possible gaps. Future studies should, and researchers are expected to find it useful to look at the basic terms related to banking fraud or crime to formulate future research trends. 
The results of the latest studies showed that the major outputs in Africa have not delved into the fourth industrial revolution (4IR) in the study of electronic banking services and systems. This revealed a gap that scholars in banking and financial studies can explore.

This study showed that mobile banking, internet banking, and electronic commerce were exhaustively covered and highly ranked. However, the results revealed that major technical research areas have not been given much priority. These include security $(f=19$, TLS $=40)$, authentication and information security $(f=17$, TLS $=33)$, computer crime $(f=16$, TLS $=42)$, automatic teller machines $(f=14$, TLS $=12)$, network security $(f=13$, TLS $=33)$ and online banking $(f=11$, TLS $=32)$. As such, future studies should consider research trajectories on these topics.

Although this study has demonstrated a growing interest in BS, research trends and the predominant focus of research in BS using bibliometric analysis, future studies should use Google Scholar database, adding search terms not used in this study or improving Boolean operators, and compare such findings to enrich the ideas gathered from this study.

\section{LIMITATIONS AND STRENGTHS}

Although this paper covered numerous parameters in studying the banking services and banking systems literature from different sources and databases, one limitation of the study is that articles not published in English were excluded. Due to many journal sources, authors and countries with low outputs were excluded as only the top outputs were displayed in the tables. Also, a recently published quality article might not have attracted many citations, whereas older articles could have received highercitations, which is a limitation. But the total outputs by institutions, authors and journal sources were used to rank outputs instead of the total citation scores. Therefore, whenever older outputs with higher citations and the new articles are included in the analysis, the researchers could include the g-index metric to solve this problem instead of using the h-index metric. Alternatively, citation count alone should not be used as a means to measure selections relevance. Nevertheless, the bibliometric analysis was an important tool in evaluating the gaps in the literature and research trends in banking industries in terms of technological innovation. The analysis can help researchers to identify gaps for future research. Institutions can use the findings to identify likely contributors with whom to collaborate, and journals with higher impact factors to submit articles to in order to increase research output's visibility. Therefore, the data obtained are reliable, replicable, and verifiable, in which the academic community in Africa and the banking industry can adjust their future priority to reflect technological integration and the fourth industrial revolution impact in driving innovation in banking system research.

\section{AUTHOR CONTRIBUTIONS}

Conceptualization: Patrick Ajibade.

Data curation: Patrick Ajibade.

Formal analysis: Patrick Ajibade.

Funding acquisition: Stephen M. Mutula.

Investigation: Patrick Ajibade.

Methodology: Patrick Ajibade, Stephen M. Mutula.

Project administration: Stephen M. Mutula.

Resources: Stephen M. Mutula.

Software: Patrick Ajibade.

Supervision: Stephen M. Mutula.

Validation: Patrick Ajibade, Stephen M. Mutula.

Writing - original draft: Patrick Ajibade.

Writing - reviewing \& editing: Stephen M. Mutula. 


\section{REFERENCES}

1. Abayomi, O. J., Olabode, A. C., Reyad, M. A. H., Teye, E. T., Haq, M. N., \& Mensah, E. T. (2019). Effects of Demographic Factors on Customers' Mobile Banking Services Adoption in Nigeria. International Journal of Business and Social Science, 10(1), 63-77. Retrieved from http://ijbssnet. com/journals/Vol_10_No_1_January_2019/9.pdf

2. African Development Bank. (n.d.). Retrieved from https://www. afdb.org/fr/news-and-events/ nigeria-ekiti-state-governor-visitsafrican-development-bank-makesa-case-for-increased-investmentin-his-region-19397

3. Agboola, A. (1970). Electronic payment systems and tele-banking services in Nigeria. The Journal of Internet Banking and Commerce, 11(3), 1-7. Retrieved from http:// www.icommercecentral.com/ open-access/electronic-paymentsystems-and-telebanking-servicesin-nigeria-1-7.pdf

4. Agwu, E. (2015). Analysis of obstacles to uptake of internet banking services in Nigeria. Research Journal of Business and Management, 2(1), 99-104. Retrieved from https://agris. fao.org/agris-search/search. do? recordID=TR2016025541

5. Agwu, E. (2017). Empirical analysis of retail customers' adoption of Internet banking services in Nigeria. Journal of Internet Banking and Commerce, 22(1), 1-17. Retrieved from https://papers.ssrn.com/sol3/papers.cfm?abstract_id=3122499

6. Agwu, E., Okpara, A., Ailemen, I. O., \& Iyoha, F. O. (2014). Adoption triggers and barriers of mobile banking services in Nigeria. International Review of Social Sciences, 2(9), 374-386. Retrieved from https://www. academia.edu/8823652/Adoption_ Triggers_and_Barriers_of_Mobile_ Banking_Services_in_Nigeria

7. Ajibade, P., \& Mutula, S. M. (2018). Bibliometric Analysis of Citation Trends and Publications on E-government in Southern
African Countries: A Human-

computer Interactions and IT Alignment Debate. Library Philosophy and Practice (e-journal), 2234, 1-19. Retrieved from https:// digitalcommons.unl.edu/libphil$\operatorname{prac} / 2234$

8. Ajibade, P., \& Mutula, S. M. (2020a). An alternative approach to fostering African economic integration through the utilization and alignment of information technology. Journal of African Union Studies, 9(1), 51-66. https:// doi.org/10.31920/2050-4306/2020/ S9n1a3

9. Ajibade, P., \& Mutula, S. M. (2020b). Big Data Research Outputs in the Library and Information Science: South African's Contribution using Bibliometric Study of Knowledge Production. African Journal of Library, Archives \& Information Science, 30(1), 49-60. Retrieved from https://www.ajol.info/index. php/ajlais/article/view/196569

10. Ali, P. I., \& Kalu, E. O. (2016). Impact of automated teller machine on banking services delivery in Nigeria: a stakeholder analysis. Brazilian Journal of Education, Technology and Society, 9(1), 64-72. Retrieved from http:// www.brajets.com/index.php/brajets/article/view/251/160

11. Almirall, E., \& Wareham, J. (2008). Living labs and open innovation: Roles and applicability. The Electronic Journal for Virtual Organization and Networks, 10(3), 21-46. Retrieved from https:// www.esadeknowledge.com/view/ living-labs-and-open-innovationroles-and-applicability-151918

12. Chaudhry, B. A. (2015). Alignment of Project Management with Business Strategy. International Journal of Information Technology Project Management, 6(4), 4864. https://doi.org/10.4018/Ijitpm.2015100104

13. Coorevits, L., Seys, C., \& Schuurman, D. (2014). Living lab methodology as an assessment tool for mass customization. Paper presented at the Proceedings of the 7th World Conference on Mass Customization, Personalization, and Co-Creation (MCPC 2014). Aalborg, Denmark, February 4th7th, 2014.

14. Essia, U., \& Anwana, E. (2012). Factors that Affect Adoption of e-Banking Products and Services in Nigeria. Sciences, 55, 123-131. Retrieved from https://www. academia.edu/15438030/Factors_that_Affect_Adoption_of_eBanking_Products_and_Services_ in_Nigeria

15. Gill, W. (2010). The reasons for the low market penetration of banking services in South Africa (MBA dissertation). University of Pretoria. Retrieved from http://hdl. handle.net/2263/23627

16. Ilo, J. V., Wilson, A., \& Nnanyelugo, S. (2014). Impact of technological innovation on delivery of banking services in Nigeria. Paper presented at the International Conference on Economics, Education and Humanities. Indonesia. Retrieved from https://icehm.org/ upload/6786ED1214048.pdf

17. Jeucken, M. (2010). Sustainable finance and banking: The financial sector and the future of the planet (320 p.). United Kindom: Routledge. https://doi. org/10.4324/9781849776264

18. John, O., \& Roitimi, O. (2014). Analysis of electronic banking and customer satisfaction in Nigeria. European Journal of Business and Social Sciences, 3(3), 14-27. Retrieved from https://pdfs.semanticscholar.org/8d53/5dff92b4b e15e06a4abf190f2e5df2740890.pdf

19. Kabanda, S., Downes, A., \& dos Ramos, S. B. (2012). Mobile Banking Services in South Africa: The case of M-Pesa. Paper presented at the INC. Retrieved from https://www.researchgate. net/publication/287236242_Mobile_banking_services_in_South_ Africa_The_case_of_M-Pesa

20. Maduku, D. K. (2011). Understanding retail bank 
customers' attitude towards and usage of cell phone and Internet banking services in Gauteng, South Africa (Dissertation). University of Johannesburg. Retrieved from https://ujcontent.uj.ac.za/vital/access/services/Download/uj:7288/ CONTENT1

21. Maduku, D. K. (2013). Predicting retail banking customers' attitude towards Internet banking services in South Africa. Southern African Business Review, 17(3), 76-100. Retrieved from https://www. ajol.info/index.php/sabr/article/ view/110928

22. Musa, H. A., Habib, M. T., \& Muhammad, F. (2018). Investigative Assessment On Customer Satisfaction with E-Banking Service Quality in Nigeria and Bangladesh. International Research Journal of Mathematics, Engineering and IT, 5(2), 1022. Retrieved from https:// www.academia.edu/36792497/ INVESTIGATIVE_ASSESSMENT_ON_CUSTOMER_SATISFACTION_WITH_E-BANKING_SERVICE_QUALITY_IN_ NIGERIA_AND_BANGLADESH

23. Nadzar, N. M. A. M., Bakri, A., \& Ibrahim, R. (2018). The Study of Co-occurrences Index's Keywords for Malaysian Publications. Paper presented at the International Conference of Reliable Information and Communication Technology. https://doi.org/10.1007/978-3319-99007-1_16

24. Ngerebo-A. T., \& Yellowe, S. (2012). The effects of corporate governance on patronage of banking services in Nigeria. Australian Journal of Business and Management Research, 2(5), 30. Retrieved from https:// pdfs.semanticscholar.org/63 bb/78df4c5ab8e8374463a64 0035bfd202bfaf6.pdf?_ga=2 .29573439.182520155.1591683117-2100778558.1584432533

25. Nnamani, M. U., \& Makwe, S. (2019). Impact of Electronic Banking on Customer Satisfaction. IDOSR Journal of Science and Technology, 4(1), 23-35. Retrieved from https://www.idosr.org/wpcontent/uploads/2019/04/IDOSRJST-41-23-35-2019.-OL.pdf
26. Nyoka, C. (2018). An examination of the factors that determine consumers' adoption of mobile banking services in South Africa. Euro Economica, 37(3), 116-129. Retrieved from http://journals. univ-danubius.ro/index.php/euroeconomica/article/view/4774/4729

27. Ogbuji, C. N., Onuoha, C. B., \& Izogo, E. E. (2012). Analysis of the negative effects of the automated teller machine (ATM) as a channel for delivering banking services in Nigeria. International Journal of Business and Management, 7(7), 180. https://doi.org/10.5539/ijbm. v7n7p180

28. Ohene-Afoakwa, E., \& Nyanhongo, S. (2017). Banking in Africa: Strategies and Systems for the Banking Industry to Win in the Fourth Industrial Revolution. Africa Expansion Project. Retrieved from https://www. bankseta.org.za/wp-content/uploads/2018/08/BA3DD51-1.pdf

29. Okereke, G., \& Ezugwu, O. (2014). Authenticating E-Banking Services in Nigeria through Digital Signatures. Editorial Board, 47. Retrieved from https://www. semanticscholar.org/paper/Authenticating-E-Banking-Servicesin-Nigeria-Okereke-Ezugwu/631 62307e48f4229c7bcc3062d5282e $7 \mathrm{f} 7675240$

30. Olowokere, E. N., \& Olufunmilayo, A. (2018). Bank-Customer Relationship and Provision of Quality Electronic Banking Services in Nigeria. Journal of Law, Policy and Globalization, 80, 133-145. Retrieved from https:// www.iiste.org/Journals/index.php/ JLPG/article/view/45846/47331

31. Ozuru, H. N., \& Opara, B. (2014). Influence of Relative Advantage on Adoption of Electronic Banking Services in Nigeria. Technoscience Review, 5(1), 17-25. Retrieved from https://www.researchgate. net/publication/313236245_INFLUENCE_OF_RELATIVE_ADVANTAGE_ON_ADOPTION_ OF_ELECTRONIC_BANKING_ SERVICES_IN_NIGERIA

32. Pezzuto, I. (2019). Turning Globalization 4.0 into a Real and Sustainable Success for
All Stakeholders. Journal of Governance and Regulation, 8(1), 8-18. Retrieved from https:// papers.ssrn.com/sol3/papers. cfm?abstract_id $=3320732$

33. Sarjiyus, O., Oye, N., \& Baha, B. (2019). Improved Online Security Framework for e-Banking Services in Nigeria: A Real World Perspective. Journal of Scientific Research and Reports, 23(1), 1-14. https://doi.org/10.9734/jsrr/2019/ v23i130113

34. Van Eck, N. J., \& Waltman, L. (2014). Visualizing bibliometric networks. In Measuring scholarly impact (pp. 285-320). Springer. https://doi.org/10.1007/978-3319-10377-8_13

35. Waltman, L., Van Eck, N. J., \& Noyons, E. C. (2010). A unified approach to mapping and clustering of bibliometric networks. Journal of Informetrics, 4(4), 629-635. https://doi. org/10.1016/j.joi.2010.07.002

36. Wang, B., Xing, D., Zhu, Y., Dong, S., \& Zhao, B. (2019). The state of exosomes research: a global visualized analysis. BioMed Research International, 2019. https://doi. org/10.1155/2019/1495130 